このよ5にシクロペンタジェニルアニオンの生成する説は著者ら の実験結果を説明する上に大変有利であるが，この機構をうらつ けるためにはさらに詳細な検討を必要とする。

終りに本研究に終始ご激励いただいた当所北川公部長, 研究全
般にわたりこ指導いただいた川松俊治主任研究員に厚くお礼申し 上げるとともに，照射にこ協力いただいた繁田道男研究員，大山 昭昌研究員ならびに実験に協力された福家元研究員に厚く感謝の 意を表します。

\title{
若干のビスシアノ化合物の合成と, シアノ化合物からトリアジン環，メラミン様樹脂の生成
}

(昭 和 39 年 2 月 28 日 受 理)

田伏 岩夫・高木 邦彦・小田良平*

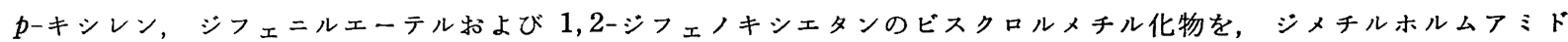

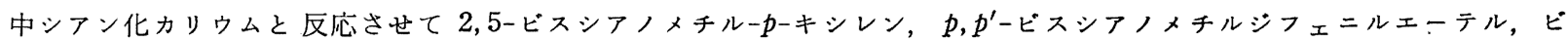
スシアノィチル-1,2-ジフェノキシェタンを合成した。またビスフェノールAをトリトン $\mathrm{B}$ 触媒でアクリロニトリルと反 応させ， $p, p^{\prime}$-ビスシアノェチルビスフェノールA を合成した。これらのビスシアノアルキル化物をカセイカリ触媒でジ シアンジアミドと反応させることにより，相当するビスー またはモノ (2-㯰換-2,4-ジアミノ-1,3,5-トリアジン) 類を新 に合成した。これらのトリアジン類はカセイカリ触媒でパラホルムアルデヒドにより人チロール化され，ハチロール化物 を熱または塩化アンモニウム添加により硬化させると，無色透明ないし淡色で強墐なフィルムを与えた。
\end{abstract}

\section{1 緒—言}

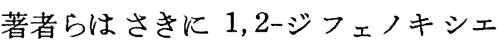
タンのクロルメチル化反応を研究し，酢 酸中リン酸触媒でパラホルムアルデヒド と塩化水素ガスにより, ビスクロルメチ ル化物が円滑に合成されることを報告し たが2)，本研究に拈いては，ビスクロル メチル化物の応用研究として, このクロ ルメチル化 1,2-ジフェノキシェタンのほか, p-キシレン, ジフ エニルェーテルのビスクロルメチル化物などを用いてビスシアノ 化合物を合成した。またこれから出発してモノー特よびビスジア ミノトリアジンを合成した。本報ではこれらの結果について記載 する。な怙著者らは種々の有機反応を応用してポリ縮合を行なら ことを研究して扣り，すでにクロルメチル化物のフリーデルクラ フッ反応によるポリ縮合 ${ }^{2}$, 芳香環を有するジアルデヒドとジケ トンのポリクライゼン縮合と縮合物の光による不溶化 ${ }^{3)}$ 牤よびブ ンテ塩の縮合連結，アリルメルカプカタンからのテロマーなど1) について報告してきた。著者らはこの継続として，上記の方法で 合成したモノー拈よびビスジアミノトリアジンをパラホルムアル デヒドによりメチロール化し，熱的に，あるいは塩化アンモニウ ムを添加してメチロール化物を硬化させて強いフィルムをえた。 本報ではこれらの結果についても記載する。

\section{2 結果}

$2 \cdot 1$ ビスシアノメチル化物, ビスシアノエチル化物の合成 ビスクロルメチル化物として $p$-キシレン, 1,2 -ジフェノキシ エタン扰よ゙ジフェニルェーテルに由来するものを用いて, ジメ

†この論文を「種々の反応によるポリ縮合（第4 報)」とす る. 第 3 報は文献 1 ).

* 京都大学工学部合成化学教室: 京都市左京区吉田.

1) 田伏, 斎藤, 小田, 工化 67,478 (1964).

2) 田伏, 高木, 長田, 小田, 工化 66,979 (1963).

3) 田伏, 谷村, 小田, 工化 66, 1717 (1963).
表 1 ビスクロルメチル化物よりビスシアノメチル化物の合成 $\mathrm{ClCH}_{2} \mathrm{RCH}_{2} \mathrm{Cl}+\mathrm{KCN} \longrightarrow \mathrm{NCCH}_{2} \mathrm{RCH}_{2} \mathrm{CN}$

\begin{tabular}{|c|c|c|c|c|c|}
\hline & & & ジメチル & ビスシアノメチ & Fル化物 \\
\hline & メチル化物 & $\mathrm{KCN}$ & (ml) & 融 $(C)^{\text {点 }}$ & 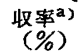 \\
\hline 8 & $\begin{array}{c}50.8 \mathrm{~g} \\
(0.25 \mathrm{~mol})\end{array}$ & $\begin{array}{c}42.4 \mathrm{~g} \\
(0.65 \mathrm{~mol})\end{array}$ & 550 & $\begin{array}{c}157 \\
\text { (茂献値 } \\
157 . \\
157\end{array}$ & 39 \\
\hline & $\begin{array}{c}50.0 \mathrm{~g} \\
(0.176 \mathrm{~mol})\end{array}$ & $\begin{array}{c}34.0 \mathrm{~g} \\
(0.53 \mathrm{~mol})\end{array}$ & 800 & 59 & 35 \\
\hline $\mathrm{CH}_{2}-$ & $\begin{array}{c}15.7 \mathrm{~g} \\
(0.05 \mathrm{~mol})\end{array}$ & $(0.13 \mathrm{~mol})$ & 600 & 136 & 58 \\
\hline
\end{tabular}

チルホルムアミド中でシアン化カリウムを反応させて相当するビ スシアノメチル化物をえた。普通この置換反応には水ーエタノー ル溶媒が用いられているが，出発物ビスクロルメチル化物がこの 溶媒に難溶性であり，溶解度の大きいジメチルホルムアミドを使 用した。表 1 に，2,5-ビスシアノメチル-p-キシレン, $p, p^{\prime}-$ ビス

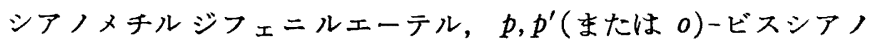
メチル-1, 2-ジフェノキシェタン合成のモル比, 収率などを記載 した。従来文献になかったビスシアノ化合物の元素分析值は, い ずれも計算値とよく一致した。

ビスフェノールAをトリトン B 触媒存在でアクリロニトリルと 反応させて $p, p^{\prime}$-ジシアノェチル化物をえた。このものも新化合 物で元素分析值は計算值と一致した。

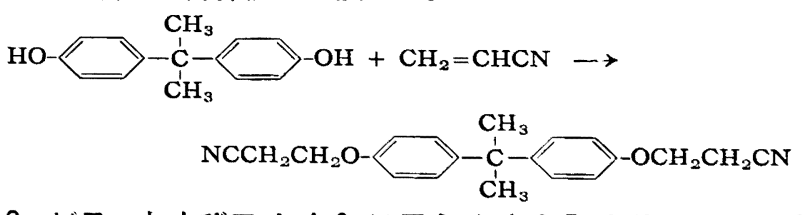

$2 \cdot 2$ ビス- およびモノ-4,6-ジアミノ-1, 3, 5-トリアジンの合 成

ニトリルとジシアンジアミドとを反応させて，2-置換-4, 6-ジ アミノ-1,3,5-トリアジン（グアナミン）をえることについては 従来多くの例が知られている。小田, 森田5) はカセイカリを触媒

4) R. B. Akin, M. T. Bogert, J. Am. Chem. Soc. 59, 1564 (1937).

5）小田, 森田, 工化 64, 659 (1961). 
にして数種のニトリルから対応するグア ナミン類をえている。アジポニトリルか らシアノブチルグアナミン6) ( I a ), ベン ゾニトリルより<smiles>[R]c1nc(N)nc(N)n1</smiles>

a $\mathrm{R}=\mathrm{NC}\left(\mathrm{CH}_{2}\right)_{1}$

b $\mathrm{R}=\left(\mathrm{CH}_{3}\right)_{2} \mathrm{~N}$

ベンゾグアナミン7), ジメチルアミノ アセトニトリルよりジメチルアミノアセ トグアナミン8) ( I b ) , rーメチル-r-アセ チルピメロニトリルから $\gamma$ メチルー $\gamma$-ア セチルピメログアナミン9（II）などの

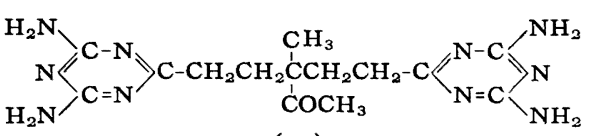
(II)

生成が特許文献に記載されている。著者 らは小田, 森田 ${ }^{5)}$ の方法によってビスシ アノメチル-p-キシレン, $p, p^{\prime}$-ビスシア ノメチルジフェニルェーテル拈よびビス シアノメチル-1,2-ジフェノキシェタン から，対応するビス特よびモノグアナミ ンの合成を行なった。結果を表 2 に示す。用いた溶媒はジメチル ホルムアミドでジシアンジアミドを 2.4 10 倍モル用い, 少量 のカセイカリを触媒として添加した。表 2 に示した反応条件では 反応液は均一となり，反応終了後生成物が沈殿になってえられる 場合にはこれを口別し，溶媒に溶けているときは水を加えて沈殿 させてから口別した。生成物の分離精製は適当な溶媒から再結 晶, または活性アルミナを充媜剤とするカラムクロマトグラフィ 一により行なった。p-キシレンのビスシアノ化合物の場合は相当 するビスグアナミンがかなりの収率で得られたが， $p, p^{\prime}$-ビスシ アノメチルジフェニルェーテル, ビスシアノメチルジフェノキシ エタンの場合はジシアンジアミドの過剩量をいろいろ変え，また 反応時間を長くしてもビスグアナミンはごく少量しかえられず， グアナミンと完全に分離できなかった。 $p, p^{\prime}$-ビスシアノメチル ビスフェノールAでは，グアナミンは全くえられずタール状物質 のみをえたが、これは技そらく逆シアノェチル化反応により、ア クリロニトリルが脱離したためと考えられる。

\section{$2 \cdot 3$ グアナミンより樹脂の生成}

グアナミンとホルムアルデヒドから樹脂を生成することについ ては多くの特許文献がある。著者らは $2 \cdot 2$ に記したグアナミン類 から同様に樹脂を生成することを確かめた。グアナミンをメチル セロソルブに溶解し, 過剰量のパラホルムアルデヒドと, 少量の カセイカリおよび水の存在下に加熱し, 反応終了後メチルセロソ ルブを減压で留去して×チロール化物をえた(表 3 に示す)。表 3 の正の場合，正に対してパラホルムアルデヒドを約 80 倍 $\mathrm{mol}$ 用いるとメチロール化物は水に可溶の粘稠な液体であり, メチ口

6) U.S.P. 2548772 ; Chem. Abst. 46, 10212 (1952).

7) U.S.P. 2684366 ; Chem. Abst. 49, 9046 (1955).

8) U.S.P. 2719156 ; Chm. Abst. 50, 13100 (1956).

9) U.S.P. 2665260 ; Chem. Abst. 48, 4882 (1954).
表 2 ビスシアノ化合物よりグアナミンの合成 $\mathrm{NH}$

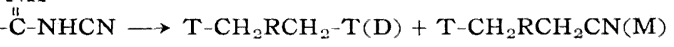

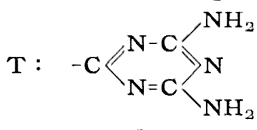

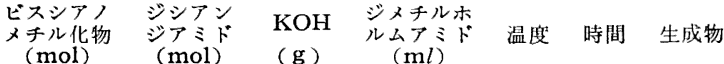

$(\mathrm{mon})$

$\begin{array}{lrrrrrr}0.1 & 0.24 & 2.2 & 200 & 140 & 6.5 & \mathrm{D}, \mathrm{M} \\ 0.02 & 0.2 & 0.5 & 50 & \text { 還流 } & 30 & \mathrm{M} \\ 0.03 & 0.3 & 0.7 & 120 & 140 & 20 & \mathrm{M}\end{array}$

表 3 グァナミンのメチロール化と, メチロール化物の硬化

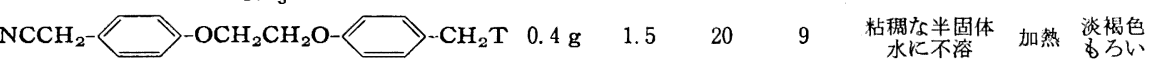

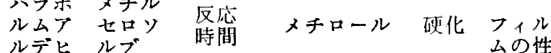
$F^{\prime}(\mathrm{g}) \quad(\mathrm{m} l) \quad(\mathrm{hr}) \quad$ 化物の性留 法 賽

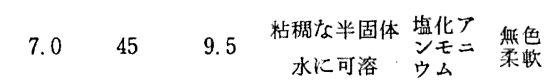

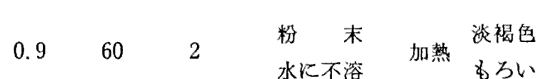

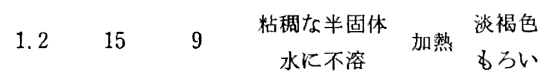
ール化が十分進んだるのと思われる。正に対してパラホルムアル デヒドを 10 倍 $\mathrm{mol}$ 用いると水に不溶な粉末がえられたが, こ れはメチロール化が不十分なものと考えられる。表 3 のすべての 場合, メチロール化物が水に可溶なときは塩化アンモニウム水溶 液により，また不溶の場合は加熱により硬化させた。

えられたフィルムは有機溶媒に不溶でジメチルホルムアミド等 でも徐々に膨潤するのみであった。濃硫酸には徐々に溶解した。

\section{3 実験}

\section{$2 \cdot 5$ ビスシアノメチルーp-キシレンの合成}

$\alpha^{1}, \alpha^{4}$-ジクロルジュレンを $p$-キシレンとホルマリン, 塩酸か ら合成 ${ }^{10)}$ し, このもの $50.8 \mathrm{~g}$ をジメチルホルムアミド $550 \mathrm{ml}$ に溶解, これにシアン化カリウム $42.4 \mathrm{~g}$ を水 $70 \mathrm{ml}$ にとかし

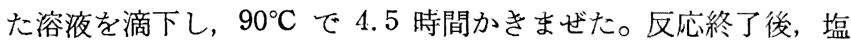
化カリウムを口去し, 水 $1.5 l$ を加えて生成物を沈殿させ, 沈殿 を水洗した。エタノールージメチルホルムアミドで 3 回再結晶す ると $\mathrm{mp} 157^{\circ} \mathrm{C}$ の白色粉末 $18 \mathrm{~g}$ を光た。精製後の収率 $39 \%$ 。

\section{$\boldsymbol{p}, \boldsymbol{p}^{\prime}$-ビスシアノメチルジフェニルエーテルの合成}

$p, p^{\prime}$ ビスクロルメチルジフェニルェーテルをジフェニルェー テルのビスクロルメチル化で合成 ${ }^{11)}$ し，これを上と同様の方法で シアン化カリウムと反応させた。反応終了後, ジメチルホルムア ミドを減圧留去して濃縮させてから水を加えてジシアノメチル化 物を沈殿させた。エタノールから再結晶， $\mathrm{mp} 59^{\circ} \mathrm{C}$ 。収率 $35 \%$ 。

分析 值 C $77.70 \%, \mathrm{H} 5.12 \%, \mathrm{~N} 11.47 \%$ $\mathrm{C}_{16} \mathrm{H}_{12} \mathrm{ON}_{2}$ としての計算值 C $77.40 \% ， \mathrm{H} 4.87 \% ， \mathrm{~N} 11.28 \%$ ビスシアノメチル-1,2-ジフェノキシェタンも同様に 合成し,

10) 村尾, 谷本, 小田, 工化 66, 1538 (1963).

11) H. Plieninger, L. Horn, A.Lutz, Chem. Abst. 49, 3989 (1955). 
エタノールから再結晶。 $\mathrm{mp} 136^{\circ} \mathrm{C}$, 収率 $58 \%$ 。

分析 值 C $74.11 \%, \mathrm{H} 5.80 \%, \mathrm{~N} 9.54 \%$ $\mathrm{C}_{18} \mathrm{H}_{16} \mathrm{O}_{2} \mathrm{~N}_{2}$ としての註算值 C $73.95 \%, \mathrm{H} 5.52 \%, \mathrm{~N} 9.58 \%$ ビスフェノール $\mathbf{A}$ のビスシノェチル化

Backman らのフェノールのシアノェチル化 ${ }^{12)}$ と類似の方法で 行なった。ビスフェノール A $50 \mathrm{~g}$ をアクリロニトリル $200 \mathrm{ml}$ 飞加党, 触媒としてトリトン B の $40 \%$ 水溶液 $10 \mathrm{ml}$ を添加 して，24 時間還流加熱した。反応混合物を $5 \%$ カセイソーダ水 溶液, 希塩酸水溶液扣よび水の順で洗ったのち, アクリロニトリ ルを留去。残分をメタノールから再結晶して $\mathrm{mp} 78^{\circ} \mathrm{C}$ の白色固 体 $31 \mathrm{~g}$ をえた。収率 $42 \%$ 。

分 析 值 C 75.72\%, H 6.67\%, N 8.20\%

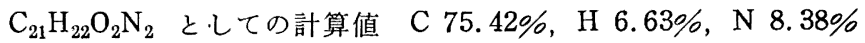
2, 5-ビスシアノメチル-p-キシレンとジシアンジアミドとの反 応

上記ビスシアノメチル化物 $18.4 \mathrm{~g}$, ジシアンジアミト $20.2 \mathrm{~g}$ 扣よびカセイカリ $2.2 \mathrm{~g}$ をジメチルホルムアミド $200 \mathrm{ml}$ に加 え, $140^{\circ} \mathrm{C} て ゙ 6.5$ 時間かきまぜた。反応終了後生成した沈殿を 熱時口過して採り, 熱水で 2 回洗浄して未反応のジシアンジアミ ドを除き，乾燥・科量すればビス置換体 $20.2 \mathrm{~g}$ (収率 $56.8 \%$ ) をえた。メチルセロソルブで 3 回再結晶して $\mathrm{mp} 314^{\circ} \mathrm{C}$ （分解） の白色固体をえた。

分 析 值 C $54.20 \%, \mathrm{H} 5.77 \%, \mathrm{~N} 39.80 \%$ ビスグアナミンとしての

計算値 C 54.53\%，H 5.72\%，N $39.75 \%$ また冷時析出した沈殿を熱水で洗ったのち乾燥すると, モノグ アナミン $6.6 \mathrm{~g}$ (収率 $24.6 \%$ ) をえた。メチルセロソルブで再 結晶して $\mathrm{mp} 285^{\circ} \mathrm{C}$ (分解) の白色固体。

分 析 值 C $62.62 \%, \mathrm{H} 6.27 \%, \mathrm{~N} 31.03 \%$ モノグアナミンとしての

計算值 C $62.67 \%, \mathrm{H} 6.01 \%, \mathrm{~N} 31.32 \%$ $\boldsymbol{p}, \boldsymbol{p}^{\prime}$-ビスシアノメチルジフェニルエーテルとジシアンジアミ ドの反応

上記の ジシアノメチル 化物 $5.0 \mathrm{~g}$, ジシアンジアミド $16.8 \mathrm{~g}$ およびカセイカリ $0.5 \mathrm{~g}$ をジメチルホルムアミド $50 \mathrm{ml}$ 中でか きまぜながら 30 時間還流加熱した。反応終了後, 熱時不溶分を 口別，熱水で洗い乾燥して黄褐色粉末 $1.5 \mathrm{~g}$ をえた。このもの はN 含有率が高く $(50.3 \%)$ 有機溶媒に不溶で, $360^{\circ} \mathrm{C}$ まで軟化 しない。

冷時に析出した沈殿をロ別し乾燥すると少量のタール状物質を 含む褐色の固体 $1.8 \mathrm{~g}$ をえた。さらに口液に水を加光て生じた 沈殿を洗浄・乾燥して黄色の粉末 $1.7 \mathrm{~g}$ をえた。両者を合せ, カラムクロマトグラフィーにより分離精製を行った。すなわち固 体混合物 $2.4 \mathrm{~g}$ をメチルセロソルブ $15 \mathrm{ml}$ に溶解し, 活性アル ミナに吸着させ，エタノールで展開・溶出させた。最初に溶出さ れた液から溶媒を留去し，兄られた固体をメチルセロソルブーエ タノール混合溶媒で再結晶して $\mathrm{mp} 200^{\circ} \mathrm{C}$ の白色固体 $1.1 \mathrm{~g}$ を

12) G. B. Backman, H. A. Lavine, J. Am. Chem. Soc. 70, 599 (1948).
えた。このものの $\mathrm{N} \%$ 実測值は 25.35 で，相当するモノグア ナミンとしての計算值 N\% 25.29 と一致した。その後に溶出す る部分は $\mathrm{N} \%$ が多く，モノー拈よびビスグアナミンの混合物と 考えられる。溶出されずに，カラムに残存するものの $\mathrm{N} \%$ は 30.49 で, ビスグアナミンとしての計算值 $33.64 \%$ よりかなり低 く,ビスグアナミンを単離することはできなかった。 ビスシアノメチル-1,2-ジフェノキシェタンとジシアンジアミ ドとの応

ビスシアノメチル-1,2-ジフェノキシェタン $8.7 \mathrm{~g}$, ジシアン ジアミド $25.2 \mathrm{~g}$ 打よびカセイカリ $0.7 \mathrm{~g}$ をジメチルホルムアミ ド $120 \mathrm{~m} l$ に加え, $140^{\circ} \mathrm{C} て ゙ 20$ 時間かきまぜた。水 $1 l$ を加え て反応生成物を沈殿させ，熱水で洗って，乾燥すると，白色粉末 $12.7 \mathrm{~g}$ をえた。これをメチルセロソルブ $100 \mathrm{ml}$ に溶かし, 活 性アルミナに吸着させ, 上と同様にメチルセロソルブーエタノー ルの $1: 1$ 混合液で展開溶出した。最初に未反応のビスシアノメ チル化物 $1.5 \mathrm{~g}$ が溶出され，ついでモノグアナミン $4.8 \mathrm{~g}$ が溶 出された。メチルセロソルブーエタノールで再結晶して, mp 225 $\sim 226^{\circ} \mathrm{C}$ の白色粉末を得た。収率 $42.5 \%$ 。

分 析 值 C $63.71 \%, \mathrm{H} 5.83 \%, \mathrm{~N} 22.27 \%$

モノグフナミンとしての

計算值 C $63.82 \%, \mathrm{H} 5.36 \%, \mathrm{~N} 22.33 \%$

アルミナ上に吸着されているものを，さらにメチルセロソルブ で溶出すると $\mathrm{mp} 240^{\circ} \mathrm{C}$ の粉末が少量えられた。このものの $\mathrm{N}$ \% は 28.09\% でビスグアナミンの計算值 $30.42 \%$ よりかなり低 く，ビスグアナミンとモノグアナミンの混合物と考えられる。 ビスシアノェチル化ビスフェノール $\mathbf{A}$ とジシアンジアミドの反 応

シアノェチル化物 $3.34 \mathrm{~g}$ ，ジシアンジアミド $2.08 \mathrm{~g}$ およびカ セイカリ $0.22 \mathrm{~g}$ をジメチルホルムアミド $30 \mathrm{ml}$ にとかし, 140 ${ }^{\circ} \mathrm{C}$ で 5.5 時間かきまぜたのちジメチルホルムアミドを减圧で留 去すると，褐色のタール状物質のみえられた。またメチルセロソ ルブを溶媒に用いて 3 時間還流させたのち溶媒を留去するとター ル状物質とともに固体がえられたが，水より再結晶した mp 150 ${ }^{\circ} \mathrm{C}$ 付近のものは $\mathrm{N} \% 3.52$ で脱シアノエチル化物に由来する副、 反応物と考觉られ，いずれも希望のグアナミンはえられなかっ た。

\section{グアナミンのメチロール化および硬化}

モノーあるいはビスグアナミン， パラホルムアルデヒドおよび 少量のカセイカリおよび水をメチルセロソルブに加え, 表 3 記載 のような条件で還流加熱したのち，メチルセロソルブを减圧で留 去してメチロール化物を粘稠な半固体あるいは粉末として党た。 たとえばயII, 10 倍 $\mathrm{mol}$ 量のパラホルムアルデヒドからえられ た水に不溶の粉末は $\mathrm{N} \% 22.25$ で, メチロール基の数は 1 分子 当り 6.7 個に当る。これらメチロール化物の IR 吸収は $\mathrm{OH}$ の 特性吸収を示した。えられたメチロール化物は精製せずにそのま ま水溶液にして少量の塩化アンモニウムを添加放圆する方法，ま たは水に不溶のものをそのまま粉末でガラス板に挾んで加熱する 方法によりフィルムとした。 